\title{
Productivity Enhancement at Molding Compound Manufacturing Plant by Applying Time and Motion Analysis
}

\author{
Muhammad Waseem ${ }^{1 a}$, Usman Ghani ${ }^{2}$, Tufail Habib ${ }^{1 b}$, Sahar Noor ${ }^{1 c}$, Tauseef Khan ${ }^{1 d}$
}

RECEIVED ON 22.08.2019, ACCEPTED ON 03.03.2020

\begin{abstract}
Commercial boundaries have been erased by markets globalization. Companies around the world compete with each other and thus are enforced to improve their products and processes. These improvements depend on a number of factors such as proper management, working environment, and available technology, etc. Inappropriate design of the working environment is one of the main reasons for lower productivity. Inadequate and incomplete working environments caused by ignoring standard methods in planning level, persistent physical disorders and increase mistakes impact the productivity in the working environment. Maximum productivity, with less physical load and energy consumption, is achieved when the compliance occurs between worker and task.
\end{abstract}

This paper aims to optimize ineffective time and eliminate undesired operations at Molding Compound Manufacturing plants using the time and motion study techniques. The results represent a significant improvement in the production process in productivity and cycle time to optimize the system. There is a substantial increase in the production of the product by simplifying the working method and changing the work sequence. Productivity is improved by eliminating unnecessary movements, simplifying individual tasks and changing operations sequence. Results show that time for each milling operation reduced from 36.3 minutes to $22.5 \mathrm{~min}$, the number of machines reduced from 4 to 3.48 and productivity improved from 5 bags per hour per worker to 7.14 bags per hour per worker.

Keywords: Productivity Enhancement, Work Study, Time and Motion Study, Molding Compound, Process Analysis.

\section{INTRODUCTION}

I ndustrial automation has affected the number of workers in the industries. Now, there are fewer requirements for humans in industries. Technology has replaced the human labors in the developed countries but still, there is a need to focus on labor efficiency in the developing and underdeveloped countries. The technology required to replace these human interventions is not feasible economically for these countries. At the same time, these industries have to compete in the national and international markets which is a challenging task. To sustain in this globalized world, these industries must have an efficient working system in order to utilize every working moment. Without having a workerfriendly environment, this system cannot be achieved and the productivity will be disturbed.

Almost all local industries are lacking in proper safety measures and methods. There are standard operating procedures defined for each work but there is no

${ }^{1}$ Department of Industrial Engineering, University of Engineering and Technology, Peshawar, Pakistan.

Email: ${ }^{\mathrm{a} m w a s e e m @ u e t p e s h a w a r . e d u . p k}$ (Corresponding Author), ${ }^{\mathrm{b}}$ tufailh@uetpeshawar.edu.pk,

csahar@uetpeshawar.edu.pk, ${ }^{\mathrm{d}}$ uetian246@gmail.com

${ }^{2}$ Department of Mechanical Engineering, University of Engineering and Technology, Peshawar, Pakistan.

Email: usmanghani@ uetpeshawar.edu.pk

This is an open access article published by Mehran University of Engineering and Technology, Jamshoro under CC BY 4.0 International License. 
monitoring over there. Further, these SOPs have been developed since the beginning of these industries that need to be updated. Most of the workers are lacking in education that do not know how to perform a task in a proper manner so that high efficiency is achieved with less effort. Financial development of any industry to a great extent relies upon limiting excess work and productivity improvement. To minimize excess work and improving efficiency at first we ought to understand the production term. Production is a process or strategy created to transfer a set of input into output legitimate quality and quantity along these lines accomplishing the targets of an industry. Production makes items by the change of raw materials [1]. Workstudy and methods engineering considers all these aspects to improve the overall performance without any investment.

Work Study is an imperative administration tool which is used to examine the work done in an organization and aims at finding the best and most efficient way of utilizing the available resources to gain quality of work in minimum possible time. [2] initiated a time to study in the 18th century in a steel company. He studied the performance of workers and measured physical work in terms of horsepower. Later on, [3] introduced a motion study to identify the optimum method for a task with less effort. Another study [4] worked on the association of time and motion study with productivity and profitability. $\mathrm{He}$ further identified different factors, influencing the efficiency improvement. Factors like labor, material, land, and machine, etc. were discussed but their mutual relationship and the change in effect when the combination differs are neglected. Another author related time and motion study to administration benefits. He discussed that administrations benefits are directly associated with work-study and methods engineering. In the research literature, different factors related to work-study and methods engineering have been identified and discussed its effects on productivity. However, in addition to identifying and discussing individual factors, there is also need of interrelation of the factors and the type of industry being considered for the study as these factors are unique for each industry [4]. The use of method study and work measurement is broadly utilized tool in manufacturing industry as well as service industry [5].

Therefore, this paper identifies the relationship between the type of industry and its productivity in terms of work-study and methods engineering. It considers molding compound plant as a case study to identify the unnecessary activities being carried out in the production process and then improves productivity by eliminating these tasks such as,

- To minimize unnecessary motion associated with the task by memo study of activity engaged with the milling section.

- To minimize the ineffective time in each operation

- To propose a new method for performing a particular activity and contrasting it and the current technique for a task.

This paper studies the molding compound powder manufacturing process. Data is collected for the existing process and is analyzed to remove unnecessary operations. Additionally, the interaction of factors, contributing to productivity, with each other is studied and relation on type of industry is discussed. The significance of this research work is associated with a decrease of counterproductive time and improves productivity.

The rest of the paper is divided into following sections: next section describes the literature work in this area; then the methodology and data collection of the production system is presented followed by the improved working system, results, and discussion. Finally, the last section concludes our work and presents recommendations for improvement.

\section{LITERATURE REVIEW}

Work study was originally evolved in engineering. The colonist of the analytical study of work was Charles Babbage who came out with a book called The Economy of Machinery Manufactures in 1832. It became very popular both in Britain and abroad. He wrote about the use of benchmark for studying work and recording facts about it, and reflection on the use of the stopwatch for timing operators at work. He 
studied the performance of workers and measured physical work in terms of horsepower [6]. Gilbreth [3] and his wife introduced "Motion Study" which studied human beings at work in a prescribed period of time. Afterwards, several techniques of the work-study have been introduced respectively up to the present time [7].

As mentioned by [9] effective production includes less production time and higher efficiency. Work study aims to identify non value added activities and inefficient utilization of resources that impact productivity. Work Study has a coordinate associated with the profitability. It is used to expand the sum created from a given amount of assets with minimum further risks [8]. Efficiency improvement is influenced by different factors, for example, Labor, Material, Land, Machine, Capital, Technology, item, and Management. One of the compelling methods for bringing enhancement up, in the long run, is the improvement of the new process and establishment of present-day plant and hardware. But this methodology requires substantial capital venture [8].

Work study is a term used to suggest comprehensively to every one of the procedures of technique study and work measurements which are utilized to guarantee the best possible utilization of human and material assets in doing a particular job [9]. Other study [10] expressed that work examination is helpful in administration of the process. Study and work measurement, is utilized in the examination of human work in the entirety of its unique circumstances, furthermore, which prompt the deliberate examination of all the action and elements influencing the proficiency and economy of the circumstance being looked into, with the end goal to impact enhancement. [11] work study as a precise methodology including three fundamental systems: strategy development, work measurement, and work assessment. The other investigation discussed the significance of "Movement Study" which thinks about people at work in a predetermined timeframe. In the literature various studies discuss that how the work study can be used for productivity improvement in various fields such as horticulture, retail exchange, healing centers etc. with the end goal to move forward profitability and accomplishing the objective with the more proficient process [12].

Productivity improvement is significant for any sorts of industry. Improving productivity is one of the crucial issues to utilize resources efficiently. Productivity improvement serves to satisfy customer and decrease time and cost to create better products [13]. The International Labor Office used to keep up that there was nothing surprising about the investigation and refinement of activities in the workshop or working environment; great supervisors had been investigating and improving as far back as human effort had been composed in a significant huge scale, and that more likely than not been well before the Pyramids were made in Egypt [14].

Rantala et al. [15] identified different obstacles restraining productivity improvement. Employee's lack of knowledge and education was identified as one of the major obstacle. Improper postures and ergonomic problems affect the workers in negative way. Productivity is affected when poor working postures are used [16]. Cirjaliu proposed a framework for improving productivity through workplace improvement and quality tools [17]. Umarkar et al. [18] defined three methods for improving the productivity; mechanization, standardization and work-study. Effective production requires high utilization of workers but this requirement must be supported by suitable working conditions and friendly environment [19].

In fact, productivity can almost always be greatly raised up by heavy capital investment in the forms of new and improved plant, equipment, and places. Productivity incorporates successful relationship to performance measure for strategy use, technique yield, cost of item, and work in process level and on time delivery [20]. Productivity is viewed as a growth of benefit [21]. The research and development necessary to elaborate on a new process, new equipment, or technology of higher interpretation are usually expensive and time absorbing. On the other hand, now a day's work-study has been used to increase productivity through achieving its systematic procedures; in fact, an ordinary man can accomplish results as good as or sometimes excel than a less 
systematic genius.

How much can we look for to gain through the use of management techniques? The work study does not require any heavy investments and can be applied to any type of organization. It is a systematic approach to effective production [22].

\section{RESEARCH METHODOLOGY}

The research process consists of several steps, as shown in Fig. 1. First, a detailed study was conducted on the manufacturing processes of the proposed industry to understand the existing issues. It has been observed that the proposed company is using traditional manufacturing processes with no consideration of improving the molding compound powder production. After detailed literature review and problem identification, data was collected about the production process of molding compound powder. Then the framework defined for implementation of work-study and methods engineering techniques are applied to this case and obtain results. The results were analyzed to find the respective processes. Finally, based on these results recommendations were suggested to the said industry for making necessary improvements.

After studying the complete process of the company, the main focus is on milling operation to improve the production. worker to perform a single activity, is measured using stop watch. Since the activities are performed by humans, therefore there is always chances of variability in time. To mitigate this issue, three samples of reading were taken for each activity and then average value is considered for further calculations. Similar procedure is used for data collection of improved method.

\section{DESCRIPTION OF THE CASE COMPANY}

Dynea Pakistan is a private company and is recognized for molding compound powder, formalin, resin, and glaze powder manufacturing. Major raw materials used in this industry include urea and cellulose. Besides production and supply chain departments, the company has other supporting departments like mechanical, electrical and utility departments, working on conventional SOPs. For this study, a single section is considered that is explained as follows.

\subsection{Process Flow of the Molding Compound Powder}

Fig.2 shows the process flow layout of Molding Compound Powder. The process starts with raw material and ends at product packing.

The focus is on the material section as it represents the most problematic situation and the probability of improvement is higher as compare to other sections.

Data for existing parameters like time taken by the

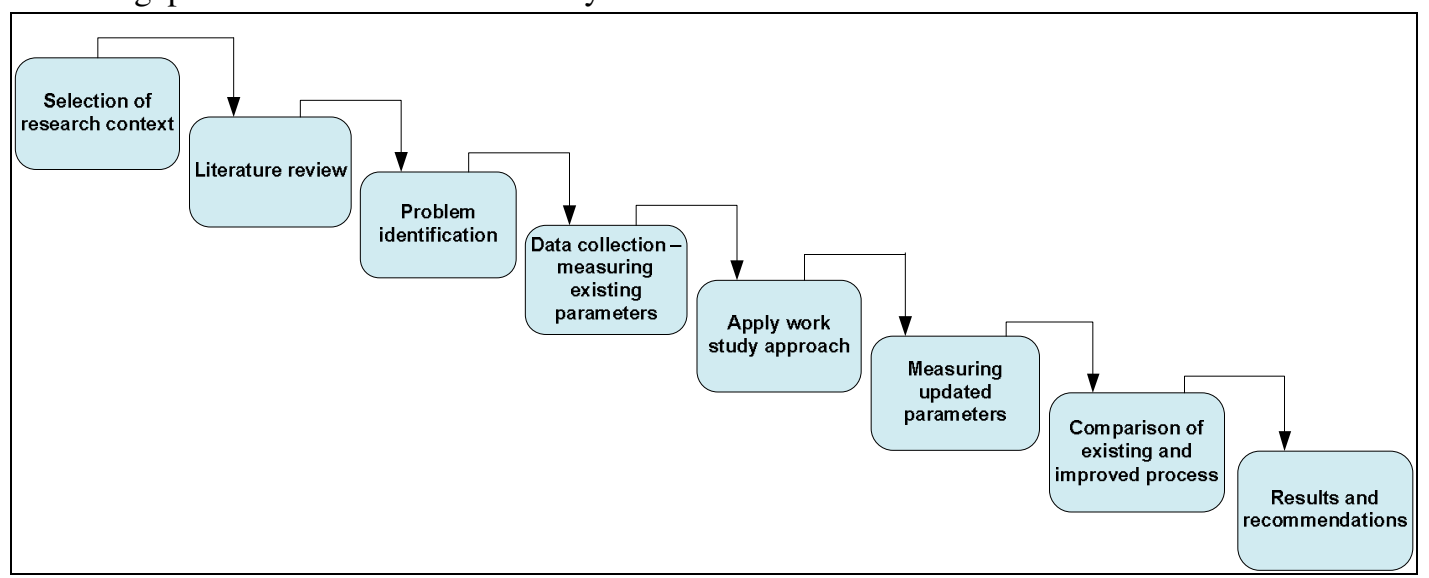

Fig. 1: Research Methodology

Mehran University Research Journal of Engineering and Technology, Vol. 40, No. 4, October 2021 [p-ISSN: 0254-7821, e-ISSN: 2413-7219] 


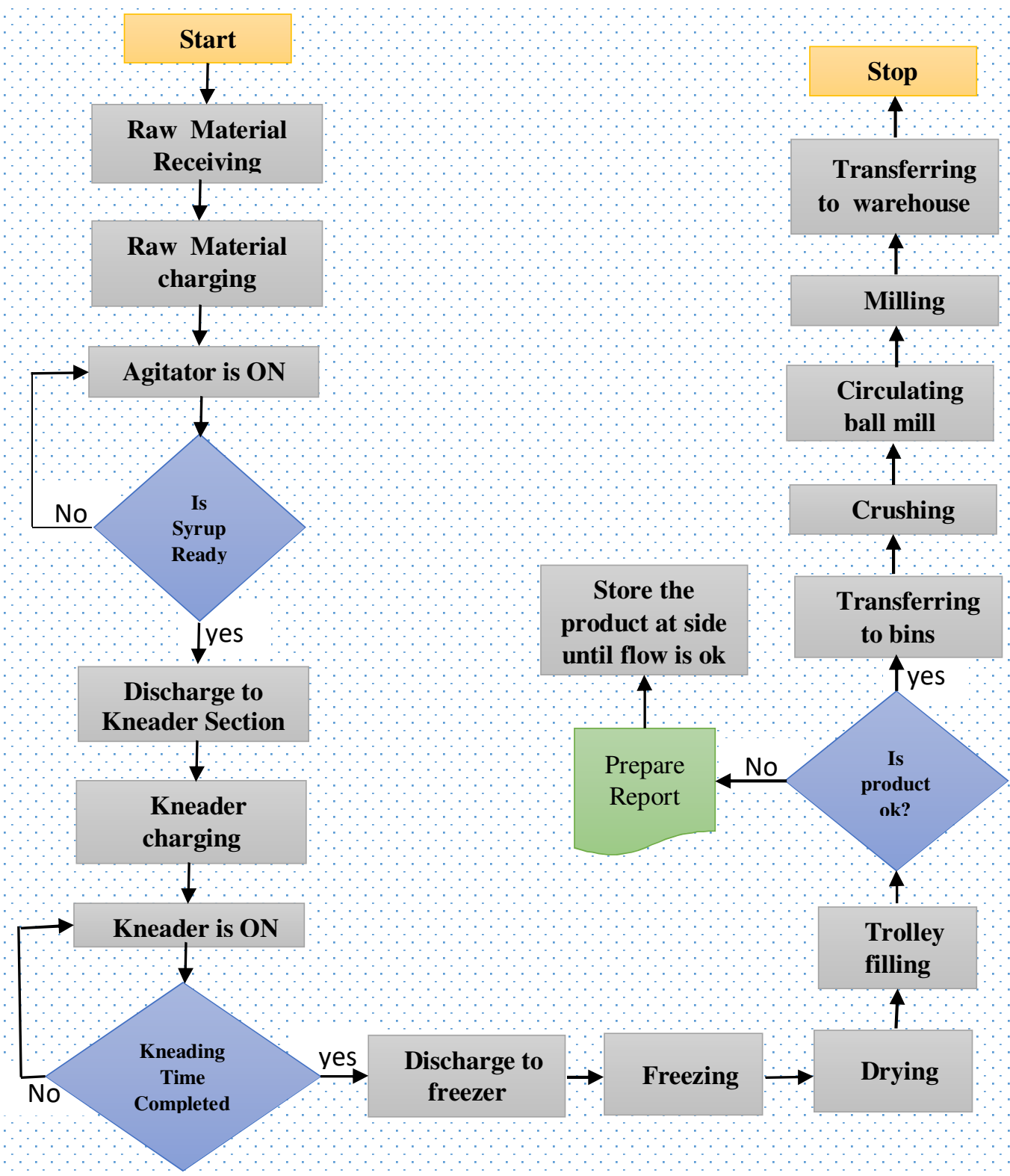

Fig. 2: Process Flow Layout in DYNEA Pakistan

It has been carried through the syrup preparation area and Kneader section, studied operations being performed in both the departments, it has bit higher issues in contrast to the material department. Milling is the last section to be evaluated for issues. It contains much higher problems in terms of timemotion study and work measurement in comparison to all the aforementioned departments that are studied in depth.

\subsection{Description of Milling Section in Production}

Process
The process starts from the syrup preparation section, resulting in syrup and proceeds to the kneading section where the syrup is mixed with additional chemicals. After kneading, the product goes through dryers for drying and is then shifted to trolleys. These trolleys transfer the product to different bins available at milling section.

In the milling section, the product from each bin is transferred to the respective ball mill through mechanized machines called Crushers. When the ball mill gets filled, it is circulated for a specific time and 
then the milling of the product starts. Vibrators are installed at the milling section that is associated with each ball mill and crusher. The vibrator has one input and two outputs. The product from the ball mill enters to the vibrator through a mechanized screw conveyor. Within vibrator, there is a mesh installed. Vibrator produces a vibration that separates the fine powder and the grain. The fine powder is received at one point and is taken as a finished product while the grain product is received at other point and is taken as the returned product. Five workers are working on this section. One for receiving of finished product and one for return product. Another worker weighs finish product bags, each bag having $25 \mathrm{~kg}$. Another person sews the bags with the help of a sewing machine. The fifth worker makes a lot of the bags on the pallet, each pallet having 35 bags each. The process layout of the milling section is given in Fig. 3.

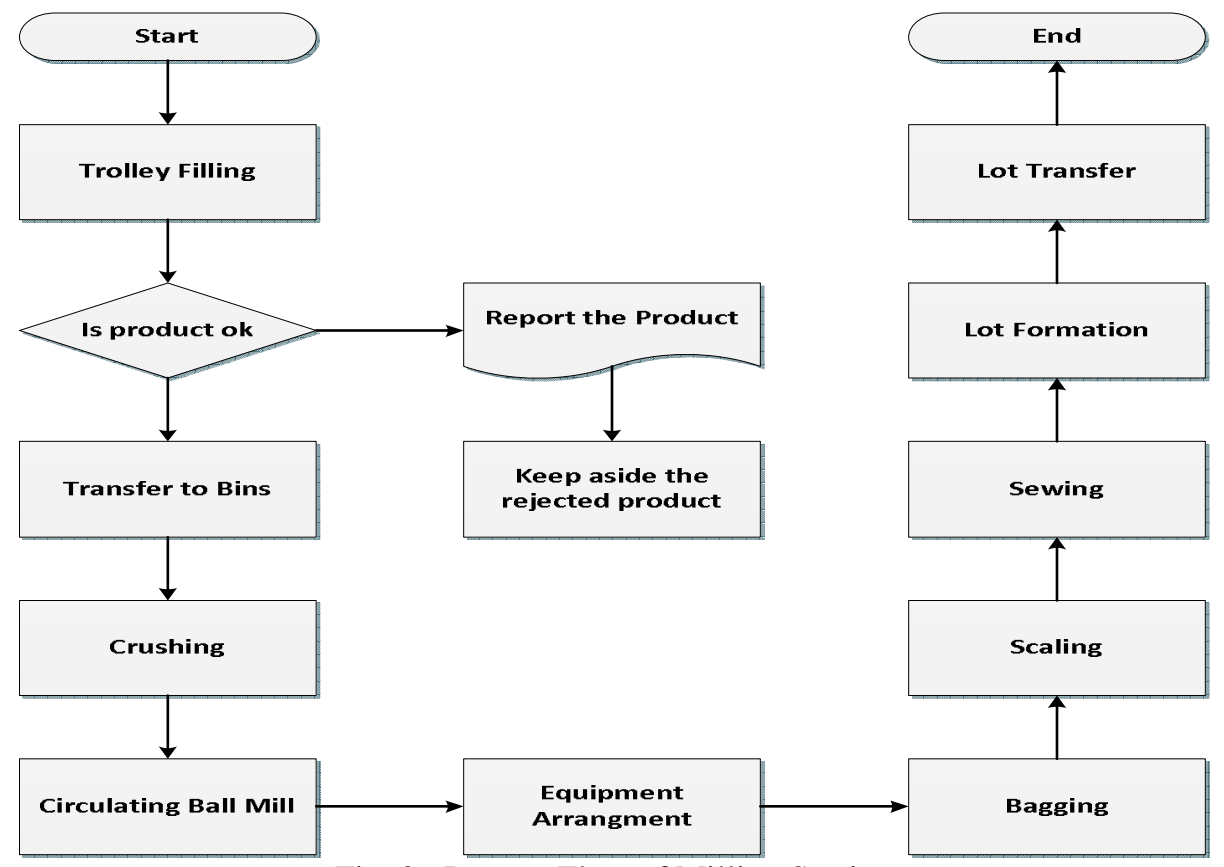

Fig. 3: Process Flow of Milling Section

\section{ANALYSIS OF PRODUCTION PROCESS}

Analysis of the process is carried out with the help of time and motion study which consist of two steps. Step one is work measurement and step two is method study.

\subsection{Work Measurement}

The essential method utilized for changing the system of work measurement is separated into six steps in particular; Determination, Recording, Analyzing, Measuring, Gathering and exactly characterizing techniques. Full steps should be performed just when standard time is to be computed. Table 1 presents data for one complete shift of fourteen hours.
Focus of this paper is just on milling section, where four ball mills are available for operation. Normally, there is one milling performed at each time during which other ball mills are either mixing the product or is waiting for filling. During the filling, the ball mill is at rest as the crusher and feeder are used to fill it, so no stop or rest time is used.

\subsection{The Study or Method Measurement}

Time study is a technique used to measure build-up time for a qualified specialist to complete a determined task under indicated conditions and at the characterized dimension of execution. Fundamental time study hardware comprises of a stop-watch, an examination load up and time consider frames. The time measuring strategy comprises of the following steps: 

Analysis

\begin{tabular}{|c|c|c|c|}
\hline \multicolumn{4}{|r|}{ Table 1: Work Measurement of the Process } \\
\hline \multirow[t]{2}{*}{ S.No. } & \multicolumn{3}{|r|}{$\begin{array}{l}\text { Process Observation Sheet } \\
\end{array}$} \\
\hline & $\begin{array}{l}\text { Time } \\
(\mathrm{min})\end{array}$ & Activities & Comments \\
\hline 1 & 15 & $\begin{array}{c}\text { Kettle } \\
\text { Charging }\end{array}$ & Urea+Formalin+Hexa is taken in Kettle \\
\hline 2 & 85 & $\begin{array}{c}\text { Syrup } \\
\text { Preparation }\end{array}$ & The agitator is started to mix the raw material \\
\hline 3 & 15 & $\begin{array}{l}\text { Kneader } \\
\text { Charging }\end{array}$ & $\begin{array}{c}\text { The prepared syrup is transferred to kneaders through pipeline and cellulose, other chemicals and } \\
\text { fluorescents are added }\end{array}$ \\
\hline 4 & 60 & Kneading & Kneader is started to mix the material \\
\hline 5 & 15 & $\begin{array}{c}\text { Kneader } \\
\text { Discharging }\end{array}$ & Product is discharged to the freezer \\
\hline 6 & 45 & Freezing & Product is freeze \\
\hline 7 & 135 & Drying & Product is dried by passing through heated boxes on mechanized conveyors \\
\hline 8 & 20 & $\begin{array}{c}\text { Dust } \\
\text { Collection }\end{array}$ & Dried Product is transferred to DC where the dust and grains are separated \\
\hline 9 & 180 & Crushing & Grains passes through crushers to fill the ball mills \\
\hline 10 & 120 & $\begin{array}{c}\text { Ball mill } \\
\text { Circulation }\end{array}$ & After filling up of ball mill, it is circulated \\
\hline 11 & 150 & \multirow[t]{3}{*}{ Milling } & \multirow[t]{3}{*}{ After circulation, the product is taken out of ball mill } \\
\hline Total & 840 & & \\
\hline Time $(\mathrm{Hr})$ & 14 & & \\
\hline
\end{tabular}

\begin{tabular}{|c|c|c|c|c|c|c|}
\hline \multicolumn{7}{|c|}{ Table 2: Existing Method Time Study } \\
\hline \multicolumn{7}{|c|}{ Existing Method } \\
\hline \multicolumn{4}{|c|}{ Time Observation Form } & \multicolumn{2}{|c|}{\begin{tabular}{|l|l|} 
Date Model & \\
\end{tabular}} & \multirow{3}{*}{$\begin{array}{r}\text { Event or Observer: } \\
\text { Comments }\end{array}$} \\
\hline \multirow[t]{2}{*}{ Step } & \multirow[t]{2}{*}{ Components Task } & \multicolumn{3}{|c|}{ Components Task Time } & \multirow{2}{*}{$\begin{array}{l}\text { Avg. Time } \\
\text { (min) }\end{array}$} & \\
\hline & & $\begin{array}{c}\text { Time } 1 \\
(\min )\end{array}$ & $\begin{array}{c}\text { Time } 2 \\
(\min )\end{array}$ & $\begin{array}{c}\text { Time } 3 \\
(\min )\end{array}$ & & \\
\hline 1 & Equipment's arrangement & 8 & 10 & 9.5 & 9.2 & $\begin{array}{l}\text { Scale, Stool, Empty bags, Ties, } \\
\text { Sewing Machines are provided }\end{array}$ \\
\hline 2 & Startup & 2.5 & 2 & 2.8 & 2.4 & $\begin{array}{l}\text { Ball mill, Vibrators, and Screw } \\
\text { conveyor is started }\end{array}$ \\
\hline 3 & Finished Product bagging & 3 & 2.8 & 3.3 & 3 & $\begin{array}{l}\text { Each bag is filled with } 25 \mathrm{~kg} \\
\text { product in about } 3 \mathrm{~min}\end{array}$ \\
\hline 4 & Return Product bagging & 3.5 & 4 & 4 & 3.8 & $\begin{array}{l}\text { This activity does not affect other } \\
\text { activities but it affects production, } \\
50 \mathrm{~kg} \text { bags are filled }\end{array}$ \\
\hline 5 & Scaling & 2 & 2.1 & 1.9 & 2 & Verification of bag weight \\
\hline 6 & Sewing & 3 & 2.7 & 3.3 & 3 & Bags are tied and sewed \\
\hline 7 & Lot formation & 4 & 3 & 3 & 3.3 & $\begin{array}{l}\text { Bags are arranged on a pallet. } 35 \\
\text { bags on each pallet (unit load) }\end{array}$ \\
\hline 8 & Lot shifting & 5 & 4.8 & 5.2 & 5 & $\begin{array}{l}\text { A unit load is shifted by pallet jack } \\
\text { to plant floor from machine }\end{array}$ \\
\hline 9 & Transfer to warehouse & 5 & 4 & 4.6 & 4.5 & $\begin{array}{l}\text { Forklift transfers unit load to } \\
\text { warehouse and place in the racks }\end{array}$ \\
\hline & Total time & 36 & 35.4 & 37.6 & 36.3 & \\
\hline
\end{tabular}

- Selection of Job

- Standardization of Method

- Select the operator for study

- Recording of details

- Measure the duration of each element

- Calculating the representative time of each element

- Convert observed time into normal time

- Calculate relaxation and other allowances

- Calculate Standard time.
Time study depends on the accuracy of a stopwatch and worker efficiency. Using time study techniques, time of each operation in the existing process is identified, given in Table 2.

\section{RESULTS}

These results are about improvement in the existing method and its time study as discussed in the following section. 


\subsection{Improvement in the Existing Method}

In the analysis of the existing method, different loopholes are observed for which a new method is introduced for the production process. Performance of the new production process method is again checked with the help of time-motion study and method engineering.

\subsection{Time Motion Study of Improved Method}

After removing the unwanted operation from the existing process, standard time for each operation is defined by counting the average time of normal healthy worker plus allowance time and a standard method for each operation is defined. Calculations for the improved method are given in Table 3 .

Although every activity is improved at some level but the major non-value added activities are: lot transfer within plant, equipment arrangement and return product bagging. Initially, the lot was first transferred within plant and then from plant to warehouse using forklift. Improved method eliminated the transfer within plant and suggested to transfer the lot directly to warehouse using forklift. Similarly, at the end of milling there is less product remained in the ball mill and thus more time is required to fill the bag. Return product is also reduced and the worker has to wait for the product. Therefore improved method suggested to assign the return point worker for equipment arrangement of next milling while the lot forming worker take care of return point. Referring to the risk of fatigue involvement, the improved method has in fact reduced the fatigue level as pulling the lot of 35 bags manually represents a high risk of musculoskeletal disorders that has been eliminated by transferring the lot directly by forklift. In case of equipment arrangement, there is no such activity involved that require wrong posture, repetitive task or too much force etc. Before, the worker was waiting to fill the bag at return point and now he makes ready another ball mill. Similarly, the lot forming worker is already waiting for finished product bags to be filled and sewed. Now he has to observe the return point also and will have to place a new bag when the old one is filled. Hence it doesn't represent any risk of fatigue as there is no such physical activity involved having potential of risk.

Fig. 4 is about the comparison of the existing and improved process.

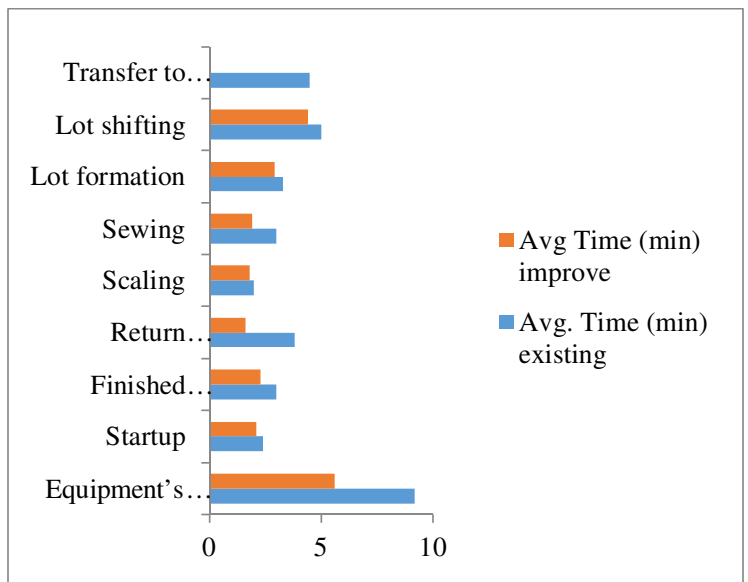

Fig. 4: Comparison of Existing and Improved Process

The standardization of times and methods is crucial by using standard data. So the following conditions are normally used:

- Identical elements are repeating consistently.

- The workload consists of similar operations, machines, products, and methods.

- All similar elements have identical start and stop motions and are spread throughout the plant.

Standard data helps to reduce or eliminate reproduction of work that is usually observed while performing time study as identical elements are timed over and over again. This results in reduced time studies, standard setting time and standard setting costs, thus increasing standard accuracy and consistency.

\subsection{Findings of Work Study Techniques}

Method study and work measurement are closely connected to each other as both are associated with work study. Method study reduces the content of the job and work measurement investigates and reduces the ineffective time associated with the job. This results in efficient working operations leading to increasing the productivity of that process. Work Measurement is the use of technique planned to

Mehran University Research Journal of Engineering and Technology, Vol. 40, No. 4, October 2021 [p-ISSN: 0254-7821, e-ISSN: 2413-7219] 


\begin{tabular}{|c|c|c|c|c|c|c|}
\hline \multicolumn{7}{|c|}{$\begin{array}{c}\text { Table 3: Improved Method of Time and Mot } \\
\text { Improved Method }\end{array}$} \\
\hline \multicolumn{5}{|c|}{ Time Observation Form } & Date Model & \multirow{3}{*}{$\begin{array}{c}\text { Event or Observer: } \\
\text { Comments }\end{array}$} \\
\hline \multirow[t]{2}{*}{ Step } & \multirow[t]{2}{*}{ Components Task } & \multicolumn{3}{|c|}{ Components Task Time } & \multirow{2}{*}{$\begin{array}{l}\text { Avg } \\
\text { Time } \\
(\min )\end{array}$} & \\
\hline & & Time 1 (min) & $\begin{array}{c}\text { Time } 2 \\
(\min )\end{array}$ & $\begin{array}{c}\text { Time } 3 \\
(\min )\end{array}$ & & \\
\hline 1 & $\begin{array}{l}\text { Equipment's } \\
\text { arrangement }\end{array}$ & 5 & 5.5 & 6.2 & 5.6 & $\begin{array}{l}\text { During prior milling, } \\
\text { return point worker is } \\
\text { made responsible for } \\
\text { arrangements while the } \\
\text { return is supervised by } \\
\text { lot formation worker } \\
\text { for some time }\end{array}$ \\
\hline 2 & Startup & 2 & 2.4 & 2 & 2.1 & $\begin{array}{l}\text { Ball mill, Vibrators, } \\
\text { and Screw conveyor is } \\
\text { started }\end{array}$ \\
\hline 3 & $\begin{array}{l}\text { Finished Product } \\
\text { bagging }\end{array}$ & 2.2 & 2 & 2.7 & 2.3 & $\begin{array}{l}\text { Each bag is filled with } \\
25 \mathrm{~kg} \text { product in about } 3 \\
\text { min }\end{array}$ \\
\hline 4 & $\begin{array}{l}\text { Return Product } \\
\text { bagging }\end{array}$ & 2 & 1.5 & 1.3 & 1.6 & $\begin{array}{l}\text { A hook is installed at } \\
\text { this point at which the } \\
\text { bag is attached, so } \\
\text { worker involvement is } \\
\text { reduced. }\end{array}$ \\
\hline 5 & Scaling & 2 & 1.7 & 1.6 & 1.8 & $\begin{array}{l}\text { Additional scale is used } \\
\text { at bagging point }\end{array}$ \\
\hline 6 & Sewing & 2 & 1.7 & 1.9 & 1.9 & $\begin{array}{l}\text { WD Spray is used for } \\
\text { the machine so } \\
\text { disruptions are reduced }\end{array}$ \\
\hline 7 & Lot formation & 3 & 2.8 & 2.8 & 2.9 & $\begin{array}{l}\text { Bags are placed at the } \\
\text { side. After completion, } \\
\text { a lot is formed so } \\
\text { individual bag timing is } \\
\text { reduced. }\end{array}$ \\
\hline 8 & Lot shifting & 4.2 & 4.8 & 4.2 & 4.4 & $\begin{array}{l}\text { A unit load is shifted by } \\
\text { forklift directly to the } \\
\text { warehouse }\end{array}$ \\
\hline & Total time & 22.4 & 22.4 & 22.7 & 22.5 & \\
\hline
\end{tabular}

establish the time for a fit worker to carry out a stipulated job at a defined level of performance.

\subsubsection{Number of Machines}

The number of bags of product depends upon the demand. On average, about 1000 bags are required for 24 hours of production. On the basis of time study, about 3.0 minute of time is required for a worker working at a normal pace to manufacture a single bag of the product. Available time for a single day that comprises of two shifts is 1440 minutes. Time for meal breaks and other adjustment is approximated as 180 minutes. Hence the net time available for production @ 100\% efficiency is

$1440-180=1260 \mathrm{~min}$

The efficiency of the plant from the previous record could be averaged as $69 \%$ hence the available time on the basis of this estimated efficiency is

$0.69 \times 1260=869.4 \mathrm{mins}$

Time required per unit bag $=\frac{869.4}{1000}=0.86 \mathrm{~min} / \mathrm{bag}$ 
This time is the actual rate of the plant at which it is being operated. On the basis of standard time and the plant rate, a number of machines required to achieve the desired production level are find out. A number of machines are found by taking the ratio of standard time and plant rate that is:

$$
\begin{array}{r}
\text { No. of machines }=\frac{\text { Standard time }}{\text { Plant rate }}=\frac{3}{0.86} \\
=3.48 \text { Machines }
\end{array}
$$

Hence the required number of machines according to the data collected is 3.4 that could be round up to 4 . Since it is calculated for the season of high demand. On average, it may require a total of three machines throughout the year but it ensures safety stock. This parameter results in the same number of machines as the ones which are installed. There are four machines installed and four are required.

\subsubsection{Number of Workers Required}

Since the number of machines has been calculated as the required number of machine to operate the plant at a normal pace. Each machine requires people that will operate it and will perform some tasks to achieve the required target. From the data collected the time required to manufacture 500 of bags is approximately equal to 14 hours including all the breaks. After eliminating the breaks, time available is 12 hours that is the time at the rate of $100 \%$ efficiency. At $100 \%$ efficiency, 700 bags are expected to manufacture in the shift. Since the efficiency of the plant is $69 \%$ (on the basis of past data) therefore the time available for production remains as

Actual time available $=0.69 \times 12=8.28$ hours

The estimated daily demand for the product is 500 bags per single shift. By using this data, the number of workers can be calculated as:

No. of workers $=\left(\frac{8.28}{700}\right) \times 1000=11.8 \frac{\text { workers }}{\text { shift }}=$ $12 \frac{\text { workers }}{\text { shift }}$

About 12 workers are required to achieve the specific objective of the required demand.

\subsection{Comparison of Existing Method and Improved Method}

\subsubsection{In Terms of Method}

A total number of operation performing in the existing method is fifteen while in the improve method this operation decreases to thirteen by removing and combining certain operation. For instance, two processes namely return product bagging and lot transfer to the main floor are removed. The process flow operation is given in the Fig. 5.

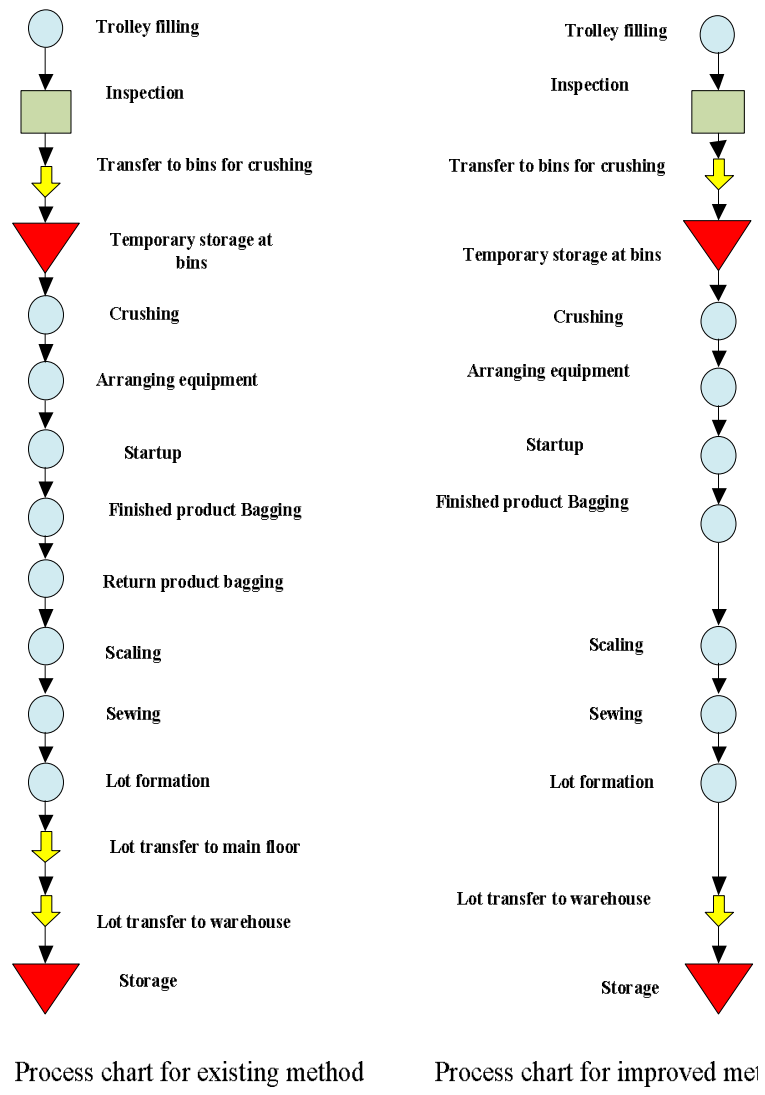

Fig. 5: Comparing Existing and Improved Process

\subsubsection{In Terms of Productivity Measurement}

Productivity is calculated as the ratio of out to input. In this case, the input is the number of man-hours while the output is the number of product bags being manufactured at the milling section. It is calculated as follows:

No.ofworkers $=7$

Hoursworkedpershift $=12 \mathrm{~h} r$ 
Total man hours $=7 \times 12=84 \mathrm{~h} r$

No. of bags manufactured per hour $=35$ bags

No.ofbagspershift $=12 * 35=420$ bags

Hence the productivity is:

\section{Existing productivity $=420 / 84=5 \mathrm{bags} / \mathrm{hr}$}

Now for the improved process, let's calculate the productivity that is given as follows:

No.ofworkers $=7$

Hours worked per shift $=12 \mathrm{~h} r$

Totalman hours $=7 \times 12=84 \mathrm{hr}$

No.ofbags manufactured per hour $=50$ bags

No. of bags per shift $=12 \times 50=600$ bags

Hence the improved productivity is:

\section{Improved productivity $=$} $600 / 84=7.14 b a g s / h r$

From the value of existing productivity and improved productivity, it is clear that productivity is improved effectively from $5 \mathrm{bags} / \mathrm{hr}$ to $7.14 \mathrm{bags} / \mathrm{hr}$.

\section{DISCUSSIONS}

In this study, the molding compound powder manufacturing of the Dynea Pakistan is conducted. From observing the overall process and method used for individual activities, it is found that most of the time is wasted in unnecessary movements. On the basis of past data, the existing efficiency of the plant was measured along with the required number of machines and workers for fulfilling the demand. Then the process was analyzed by using time and motion study and the loopholes occurring at the milling section were identified and resolved by suggesting a new method for each task. Results were collected for the new suggested methods which are discussed in the following sections.

Using work-study and methods engineering techniques significant improvement in the production process in productivity and cycle time to optimize the system is observed. For instance the results in Table 3 show that the average total time utilized in milling operation reduced from $36.3 \mathrm{~min}$ to $22.5 \mathrm{~min}$. The efficiency of the plant is found from the past data on the basis of which the required number of machines and workers are calculated in equation 1 and 2 . Figure 3 shows the complete stepwise process chart of the milling operation for the existing and improved methods and the processes are reduced to thirteen. For instance, two processes namely return product bagging and lot transfer to the main floor are removed. Figure 5 represents a graphical result for both the existing and improved processes. Improvement in each task can be easily observed. Transferring of a lot within the plant is completely eliminated by direct shipment to the warehouse.

As discussed by [9] effective production includes less production time and higher efficiency. Work study aims to identify non value added activities and inefficient utilization of resources that impact productivity. Our results shows that total number of operation performing in the existing method is fifteen while in the improve method this operation decreases to thirteen. For instance, two processes namely return product bagging and lot transfer to the main floor are removed. Work measurement in our case study investigates and reduces the ineffective time associated with the job. This results in efficient working operations leading to increasing the productivity of that process. Similarly based on the calculations, productivity improved from 5 bags per hour per worker to 7.14 bags per hour per worker.

As mentioned in $[15,18]$ productivity improvement is one of the crucial issues to utilize resources efficiently. Productivity improvement serves to satisfy customer and decrease time and cost to produce better products. In our case study, non value added activities such as lot transfer within plant, equipment arrangement and return product is identified. Then from the analysis an improved method eliminated the transfer within plant and suggested to transfer the lot directly to warehouse using forklift. Similarly, at the end of milling there is less product remained in the ball mill and thus more time is required to fill the bag. Return product is also reduced and the worker has to wait for the product. The improved method suggested to assign the return point worker for equipment arrangement of next milling while the lot forming worker take care of 
return point. By this way overall time in milling operation reduced from $36.3 \mathrm{~min}$ to $22.5 \mathrm{~min}$. So by removing the non value added activities and reducing time has improved productivity by reducing the overall costs.

Standard data helps to reduce or eliminate reproduction of work that is usually observed while performing time study as identical elements are timed over and over again. This results in reduced time studies, standard setting time and standard setting costs, thus increasing standard accuracy and consistency. Almost all of these improvements are related to the methods being used for the implementation of the task. Additionally, the sequence of the tasks is adjusted. Concurrent steps are used to increase workers and machine utilization.

\section{LIMITATIONS OF THE STUDY}

Productivity has been improved significantly by this study but there are some limitations of this research. This study has been carried out by considering a petrochemical industry and it may not be feasible for other types of industries. This study suggests new postures for specific works that might changes with changes in workplace. Additionally the suggested postures were followed for just collection of data and is not regularly implemented due to which long term results are not sure.

\section{CONCLUSION}

In this research, time-motion study and method engineering have been applied in molding compound manufacturing company. Several loopholes in the existing production setups are identified and eliminated through method engineering. The objective of this research is to expose the company to time-motion study and method engineering for the very first time in the company for productivity enhancement and that is finally achieved. To improve productivity, it is essential to bring improvement in the existing method and increase the performance of an employee by using time motion and method study. This study improves its production process by using time-motion study and method engineering.
In this study, the manufacturing process of molding compound powder is analyzed in terms of work-study and methods engineering and new methods are suggested for the milling section. The results represent a significant improvement in the production process in productivity and cycle time to optimize the system. There is a substantial increase in the production of the product by simplifying the working method and changing the work sequence. In addition, significant results obtained are summarized here:

(i) Average total time for each milling operation reduced from 36.3 minutes to $22.5 \mathrm{~min}$.

(ii) The number of workers reduced from 13 to 12 .

(iii) The number of machines reduced from 4 to 3.48 which means the production will not be affected in case of emergency on a single machine. However, it is not advised to rely on three machines.

(iv) Productivity improved from 5 bags per hour per worker to 7.14 bags per hour per worker.

(v) The number of processes reduced from fifteen to thirteen.

\section{RECOMMENDATIONS}

DYNEA Pakistan Company can gain from this study if they act on the following recommendations,

- the production facility should change the vibrator's type to reduce the powder waste,

- the company must employ Push pull interface,

- must apply design changes in the production line to reduce the powder waste,

- reduce their raw material inventory by placing an order on a specific time period.

We have not simulated the model, so future research could focus on the simulation of the production process. Simulation can help in visualizing the effects of the changes made in the layout and process methodologies. It also helps in cost savings and reducing the risk of failure as it just requires accurate data to generate results. Simulation can further improve the process by consideration of the factors and facilities that cannot not be induced in real systems easily. Additionally, analyse the methods to reduce raw material inventory and develop models to reduce 
the transportation time between the plant and warehouse, etc. Repeat studies on other models of the same process in order to enhance the reliability of the findings would be beneficial.

\section{ACKNOWLEDGMENT}

This research work was supported by the University of Engineering and Technology Peshawar, Pakistan. Further, we acknowledge the assistance provided by DYNEA Pakistan Company especially in data collection for this research project.

\section{REFERENCES}

1. Jain K.C., Aggarwal L., "Production Planning Control and Industrial Management", 1990: Khanna, 1995.

2. Ralph M.B., "Motion and Time Study: Design and Measurement of work". 1980, John Wiley.

3. Gilbreth F.B., Gilbreth L.M., Fatigue Study: The Elimination of Humanity's greatest unnecessary waste, a first step in motion study. 1919: Macmillan.

4. Schaufeli W.B., Bakker A.B., Salanova M., "The Measurement of Work Engagement With a Short Questionnaire: A Cross-National Study”, Educational and Psychological Measurement, Vo. 66, No. 4, pp. 701-716, 2006.

5. Ozor P.A., Orji-Oko C.L., Olua C.K., "Productivity Improvement of Small and Mediu m Scale Enterprises using Lean Concept: Case Study of a Bread Factory", European Journal of Business and Management, Vol. 7: p. 73-84, 2015.

6. Frankel R., Bolumole Y.A., Eltantawi R.A., Paulraj A., Gundlach G.T., "The Domain And Scope Of SCM's Foundational Disciplines - Insights and Issues to Advance Research", Journal of Business Logistics, Vol. 29, No.1, pp. 1-30, 2008.

7. Katzell R.A., Guzzo R.A., "Psychological approaches to productivity improvement", American Psychologist, Vol. 38, No.4, p. 468-472, 1983.

8. Buxey G., "Production scheduling: Practice and theory", European Journal of Operational Research, Vol. 39, No. 1, pp. 17-31, 1989.

9. Deming W.E., "Improvement of quality and productivity through action by Management",
National Productivity Review, Vol.1, No.1, pp. 12-22, 1981.

10. Sugimori Y., Kusunoki K., Cho F., Uchikawa S., "Toyota production system and Kanban system Materialization of just-in-time and respect-for-human system", International Journal of Production Research, 1977. Vol. 15, No. 6, pp. 553-564, 1977.

11. Krajewski L.J., King B.E., Ritzman L.P., Wang D.S., "Kanban, MRP, and Shaping the Manufacturing Environment", Management Science, Vo. 33, No.1, pp.. 39-57, 1987.

12. Burri G.J., Helander M.G., "A field study of productivity improvements in the manufacturing of circuit boards", International Journal of Industrial Ergonomics, Vol. 7, No.3, pp. 207-215, 1991.

13. Sujay B., Abhijit C., Nabanita B., "Improving Productivity Using Work Study Technique", International Journal of Research in Engineering and Applied Sciences, Vol. 6, No. 11, pp. 49-55, 2016.

14. Adam E.E., "Alternative quality improvement practices and organization performance", Journal of Operations Management, Vol. 12, No.1, pp. 27-44, 1994.

15. Rantala T., Pekolla S., Rantanen H., Hannula M., "Evolution of obstacles restraining productivity improvement", International Journal of Productivity and Quality Management, Vol. 25, No. 1, pp. 64-89, 2018.

16. Abebe B., Hasegawa H., "Application of Ethiopian Garment Industry: Improvement of Workplace Productivity through Ergonomics Management System", The Proceedings of Manufacturing Systems Division Conference 2018. 2018. The Japan Society of Mechanical Engineers.

17. Cirjaliu B., Mocan A., Boatca M.E., Draghici A., “A propose approach for continuous improvement using ergonomics and quality management knowledge and methodologies", Calitatea, Vol. 20, No. S1, 2019.

18. Umarkar M.A.P., Tatte M.A.B., Deshmukh H.M., "Productivity Improvement Through Ergonomics Approach", International Journal on Recent Technologies in Mechanical and Electrical Engineering, Vol. 5, No. 5, pp. 18-24, 2018.

19. Trojanowska J., Varela M.L.R., Kolinski A., Machado J., "A methodology of improvement of manufacturing productivity through increasing operational efficiency of the production process, in 
Hamrol A., Ciszak O., Legutko S., Jurczyk M. (Eds.): Advances in Manufacturing, Lecture Notes in Mechanical Engineering, pp. 23-32, 2018.

20. Bagri G.P., Raushan P., "Productivity improvement of forging section using work study and automation in existing axle manufacturing plant", International Journal of Mechanical and Production Engineering, Vol.2, No.6, pp. 1-4, June 2014.

21. Vergeer R., Kleinknecht A., "Do labour market reforms reduce labour productivity growth? A panel data analysis of 20 OECD countries (1960-2004)", International Labour Review, Vol. 153, No.3, pp. 365393, pp. 365-393. 2014.

22. Vijai J.P., Somayaji G.S.R., Swami R.J.R., Aital P., "Relevance of F.W. Taylor's principles to modern shop-floor practices: A benchmarking work study. Benchmarking, An International Journal, Vol. 24, No.2, pp. 445-466, 2017. 